\title{
Study on advanced treatment of wastewater by advanced oxidation based on sulfate radical
}

\author{
Qingying Ye* \\ School of environment, North China Electric Power University, Baoding, China
}

\begin{abstract}
At present, the use of water in each country increases sharply, which also brings increasingly prominent environmental pollution problems. A large amount of wastewater is discharged into the water body, which seriously pollutes the water environment. Wastewater treatment has become the focus of global environmental protection workers. Among them, advanced oxidation technology based on sulfate radical is used to treat refractory organic pollutants. The technology has good cleaning efficiency and oxidation stability. In order to improve the universality of research and application and in-depth decontamination, this free radical advanced oxidation method was applied to the advanced treatment of wastewater. However, divalent iron ions react with $\mathrm{Na} 2 \mathrm{~S} 2 \mathrm{O} 3$ very quickly, resulting in the reaction stopping soon. Therefore, zero valent iron (ZVI) is used to activate sodium persulfate to produce sulfate radical instead of divalent Fe ion. ZVI activation is applied to wastewater treatment.
\end{abstract}

\section{Introduction}

At present, the use of water in every country in the world increases sharply, which also brings increasingly prominent environmental pollution problems [1]. Although some measures have been taken to recover, treat and recycle the wastewater in the production process, a large amount of wastewater is still discharged into the water body, causing serious pollution to the water environment. Wastewater treatment has become the focus of global environmental protection workers. There are many components in sewage that directly affect the environment, such as colloidal substances, sulfonates, sugars, ketones, calcium, magnesium salts and residual sulfites. Then there is the sewage condensate. The main pollutants include methanol, ethanol, acetone, butanone, furfural and mushroom olefins. The pollutants in sewage are various, toxic and difficult to treat, so they pose a great threat to human health development. There is an urgent need for relevant research, which can not only effectively remove pollution in depth, but also realize the effect of green economy.

Advanced oxidation method is an effective method for advanced sewage treatment. Advanced oxidation is a new wastewater treatment method rising in the last century. Under this treatment method, the relevant organic pollutants in the sewage are transformed into $\mathrm{CO}_{2}, \mathrm{H}_{2} \mathrm{O}$, etc., or some substances that are easy to explain [2]. This method has the advantages of high processing efficiency, simple equipment requirements and high green. Advanced oxidation method is subdivided into ozone oxidation method, $\mathrm{O} / \mathrm{H}_{2} \mathrm{O}_{2}$ oxidation method, $\mathrm{UV} / \mathrm{O}_{3} / \mathrm{H}_{2} \mathrm{O}_{2}$, etc. Among them, advanced oxidation technology based on sulfate radical is used to treat refractory organic pollutants. The technology has the advantages of good cleaning efficiency, good oxidation stability, strong popularization, good oxidant stability and little influence by $\mathrm{pH}$ value [3].

In detail, sodium persulfate is one of them. Of course, it also has many of the above advantages, such as strong oxidation, good water solubility and low price. It has received extensive attention from researchers in the research of advanced oxidation technology. However, it is difficult to achieve the ideal effect of degradation and decontamination by sodium persulfate oxidation alone. At present, the methods of stimulating sodium persulfate to produce sulfate radical mainly include thermal activation method, illumination method, ultrasonic activation method [4], microwave activation method, transition metal activation method and so on. Divalent iron ions are widely used in advanced oxidation technology. Many previous studies have confirmed that the sulfate radical produced by sodium persulfate activated by divalent iron ion can effectively degrade aromatic organic pollutants. Therefore, in order to improve the universality and indepth decontamination of research and application, this free radical advanced oxidation method is applied to the advanced treatment of wastewater in this experiment. In order to make up for the defects of Fenton oxidation in practical application, and explore the process conditions, so as to lay a foundation for the optimization of the process in the future. However, divalent iron ions react with $\mathrm{Na}_{2} \mathrm{~S}_{2} \mathrm{O}_{3}$ very quickly, and the reaction can be completed in an instant, resulting in the rapid stop of the reaction [5]. In order to control the concentration of divalent $\mathrm{Fe}$ ions, zero valent iron (ZVI) was used to activate sodium persulfate instead of divalent Fe ions to

*Corresponding author: 1265439827@qq.com 
produce sulfate free radical. ZVI activation was applied to wastewater treatment.

\section{Experimental design and concentration determination}

In this paper, ZVI activation is applied to wastewater treatment in order to achieve better treatment effect, and the process conditions are preliminarily explored. Zero valent iron (ZVI) replaces divalent $\mathrm{Fe}$ ion to activate sodium persulfate to produce sulfate radical. Its principle is shown in formulas (1) and (2). The principle is to use $\mathrm{ZVI}$ as the source of divalent $\mathrm{Fe}$ ions, continuously release divalent $\mathrm{Fe}$ ions to activate sodium persulfate, and continuously produce $\mathrm{SO}_{4}$ negative ions to oxidize and degrade organic pollutants.

$$
\begin{array}{r}
\mathrm{Fe}^{0}+\mathrm{S}_{2} \mathrm{O}_{8}^{-} \rightarrow \mathrm{Fe}^{2+}+2 \mathrm{SO}_{4}^{2-} \\
\mathrm{Fe}^{2+}+\mathrm{S}_{2} \mathrm{O}_{8}^{-} \rightarrow \mathrm{Fe}^{3+}+\mathrm{SO}_{4}^{-}+\mathrm{SO}_{4}^{2-}
\end{array}
$$

Take $100 \mathrm{ml}$ waste water sample into $250 \mathrm{ml}$ sample, adjust the $\mathrm{pH}$ value to $2.8 \sim 3.1$ with $12 \%$ dilute sulfuric acid, add quantitative reduced iron powder, and then quickly add oxidant $\left(\mathrm{Na}_{2} \mathrm{~S}_{2} \mathrm{O}_{8}\right)$ for rapid mixing. Set the mixing time as $20 \mathrm{~min}$. After that, take out a certain amount of water sample and add $\mathrm{NaOH}$ solution to adjust the $\mathrm{pH}$ to $9 \sim 9.5$ to terminate the reaction. Then centrifuge for $26 \mathrm{~min}$ under the working condition of $3250 \mathrm{r} / \mathrm{min}$, and take the supernatant for detection. The experimental temperature was $26^{\circ} \mathrm{C}$ and the reaction time was 3 hours. 2 3 parallel experiments were performed in each group.

This part mainly gives the concentration determination method of divalent iron ion and $\mathrm{Na}_{2} \mathrm{~S}_{2} \mathrm{O}_{8}$. The concentration of divalent iron ion is determined by ophenanthroline spectrophotometry, and the determination steps are as follows. First, prepare iron standard stock, weigh $0.6985 \mathrm{~g}$ ammonium ferrous sulfate, completely dissolve it with $48 \mathrm{ml}$ sulfuric acid, and bottle it for standby. Then, prepare iron standard solution. Accurately measure $24 \mathrm{ml}$ of prepared iron standard stock solution with a pipette, add distilled water, shake well, and leave for use. Each ml contains 24.8 micrograms of iron.

Draw the standard curve below, measure $0,2,4,6,8$ and $10 \mathrm{ml}$ of iron standard solution successively with a pipette, transfer it into a $150 \mathrm{ml}$ conical flask, add about 50 $\mathrm{ml}$ of distilled water, slowly transfer it into a conical flask, add $10 \mathrm{ml}$ of $10 \%$ hydroxylamine hydrochloride, heat it, put 1 2 glass beads into it, vibrate and boil it, stop heating when $15 \mathrm{ml}$ of solution is left, and place it to cool to room temperature, Transfer the remaining solution to a $50 \mathrm{ml}$ stoppered colorimetric tube. Add a small piece of Congo red test paper into the colorimetric tube, and drop saturated sodium acetate solution into the colorimetric tube. The end point of titration is as soon as the test paper turns red. Then transfer $5 \mathrm{ml}$ buffer solution and $2 \mathrm{ml} 0.5 \%$ o-phenanthroline solution into the colorimetric tube, add distilled water to the mark, shake well and develop color for $15 \mathrm{~min}$. Then, the absorbance value was measured with an ultraviolet spectrophotometer at $510 \mathrm{~nm}$ with water as the reference. Figure 1 shows the obtained standard curve. Finally, the concentration of ferrous ion in the reaction is determined: according to the above method, the absorbance of ferrous ion in each reaction solution is measured by ultraviolet spectrophotometer at $510 \mathrm{~nm}$, and it is converted into the concentration value through the standard curve.

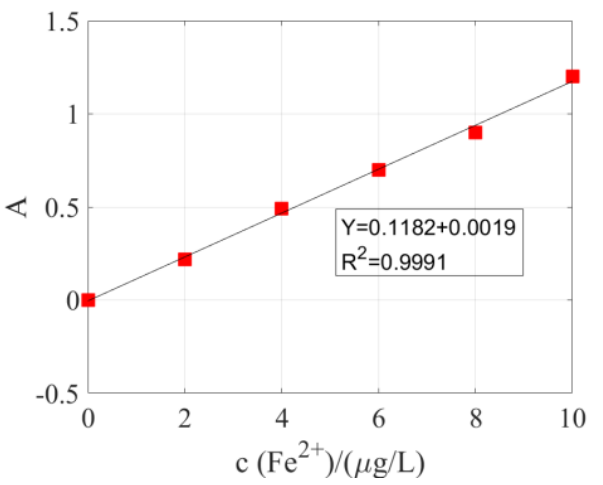

Figure 1. Ferrous ion absorbance concentration standard curve.

The determination steps of $\mathrm{Na}_{2} \mathrm{~S}_{2} \mathrm{O}_{3}$ concentration are as follows. First, prepare $\mathrm{Na}_{2} \mathrm{~S}_{2} \mathrm{O}_{3}$ storage solution. Weigh $0.0476 \mathrm{~g} \mathrm{Na}_{2} \mathrm{~S}_{2} \mathrm{O}_{3}$ powder and dissolve it in $100 \mathrm{ml}$ deionized water. After it is completely dissolved, slowly transfer it into a $1000 \mathrm{ml}$ volumetric flask, add distilled water to dilute it to the scale mark, shake it evenly and leave it for use. The solution concentration is $0.20 \mathrm{mmol} / 1$.

The absorbance concentration standard curve of $\mathrm{Na}_{2} \mathrm{~S}_{2} \mathrm{O}_{3}$ is drawn below. Take $0,2,4,6,8$ and $10 \mathrm{ml}$ $\mathrm{Na}_{2} \mathrm{~S}_{2} \mathrm{O}_{3}$ stock solution successively with a pipette into a $50 \mathrm{ml}$ colorimetric tube and dilute with distilled water; Then add $0.2 \mathrm{~g} \mathrm{NaHCO}_{3}$ and $4 \mathrm{G}$ ki into the colorimetric tube in turn and fully dissolve them. Dilute them with deionized water to the scale line, shake them evenly to fully mix them. After standing for color development for $15 \mathrm{~min}$, use unicuv-2100 UV-Vis spectrophotometer to measure their absorbance value with water as reference at the maximum absorption wavelength of $352 \mathrm{~nm}$. Figure 2 shows the standard curve drawn with $\mathrm{Na}_{2} \mathrm{~S}_{2} \mathrm{O}_{3}$ concentration as the abscissa and absorbance value as the ordinate. The concentration of $\mathrm{Na}_{2} \mathrm{~S}_{2} \mathrm{O}_{3}$ in the reaction was determined. Determine the absorbance of $\mathrm{Na}_{2} \mathrm{~S}_{2} \mathrm{O}_{3}$ in the solution to be tested in sequence according to the above steps, and convert it into the concentration value by using the standard curve.

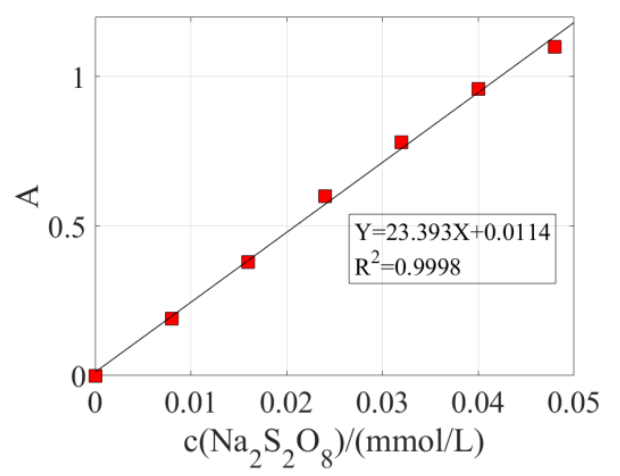

Figure 2. $\mathrm{Na}_{2} \mathrm{~S}_{2} \mathrm{O}_{8}$ absorbance concentration standard curve. 


\section{Results and analysis}

Figure 3 shows the effect of $\mathrm{pH}$ value on CODcr degradation rate and chroma removal rate of biochemical effluent from papermaking wastewater by ZVI activated $\mathrm{Na}_{2} \mathrm{~S}_{2} \mathrm{O}_{3}$ oxidation degradation. It can be seen that the CODcr degradation rate and chroma removal rate of biochemical effluent of papermaking wastewater by oxidation and degradation of $\mathrm{Na}_{2} \mathrm{~S}_{2} \mathrm{O}_{3}$ activated by ZVI decreased with the increase of $\mathrm{pH}$ value. When the initial $\mathrm{pH}$ value was 3 , the degradation effect was the best, and the CODcr degradation rate and chroma removal rate reached $41.4 \%$ and $83.5 \%$ respectively; As the $\mathrm{pH}$ value increased gradually, the degradation effect began to deteriorate, and the downward trend suddenly increased when the initial $\mathrm{pH}>7$; When the initial $\mathrm{pH}$ was adjusted from 7 to 10 , the degradation rate of CODCr decreased from $39.3 \%$ to $27.3 \%$. At this time, the reduction of chroma removal rate was more obvious, from $83 \%$ at initial $\mathrm{pH}=7$ to $18.5 \%$ at $\mathrm{pH}=10$. This shows that the suitable initial $\mathrm{pH}$ range for the oxidative degradation of organic matter by sulfate radical produced by ZVI activated sodium persulfate is acidic to neutral, and strong acidic conditions are more conducive to the formation of sulfate radical. The experiment shows that under the weak alkaline condition of papermaking wastewater without adjusting the initial $\mathrm{pH}$ value, the sulfate radical produced by ZVI activated sodium persulfate can still reduce the CODcr and chromaticity of papermaking wastewater, which is of great significance for the application of advanced oxidation method in papermaking wastewater engineering.

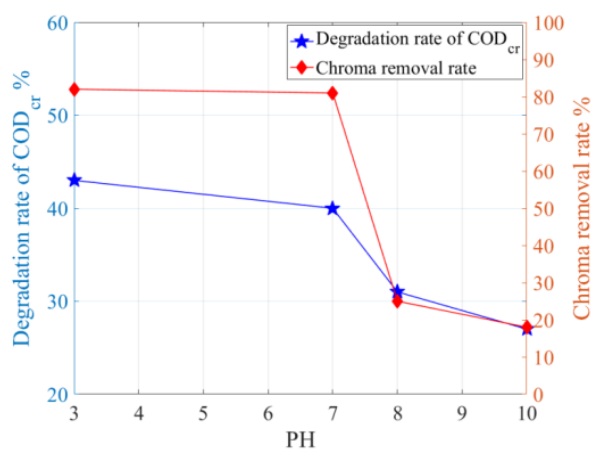

Figure 3. Effect of $\mathrm{pH}$ value on CODcr degradation rate and chroma removal rate.

The following is about the changes of pollutants in the secondary effluent of wastewater before and after advanced oxidation treatment, as shown in Table 1. Here, only 10 types are listed.It can be seen from table 1 that the refractory organics in the secondary biochemical effluent of papermaking wastewater are mostly aromatic substances with benzene ring and long-chain alkanes. After the oxidation and degradation of sulfate radical, the benzene substances in the wastewater have been degraded to a certain extent, the relative content has changed to a certain extent, and the types have basically not changed. This may be due to the competitive consumption of sulfate radical by various organic pollutants. The type and content of alkanes increased significantly, indicating that the pollutants were further oxidized and degraded.
Table 1. Changes of pollutants in wastewater before and after advanced oxidation treatment.

\begin{tabular}{|c|c|c|c|c|c|}
\hline $\begin{array}{l}\text { Num } \\
\text { ble }\end{array}$ & $\begin{array}{l}\text { retent } \\
\text { ion } \\
\text { time/ } \\
\text { min }\end{array}$ & $\begin{array}{l}\text { Compou } \\
\text { nd name }\end{array}$ & $\begin{array}{l}\text { Chem } \\
\text { ical } \\
\text { formu } \\
\text { la }\end{array}$ & $\begin{array}{l}\text { Relati } \\
\text { ve } \\
\text { conte } \\
\text { nt } \%\end{array}$ & $\begin{array}{c}\text { Confide } \\
\text { nce } \%\end{array}$ \\
\hline 1 & 4.729 & $\begin{array}{c}\mathrm{N}- \\
\text { octane }\end{array}$ & $\begin{array}{c}\mathrm{C} 8 \mathrm{H} 1 \\
8\end{array}$ & 1.312 & 24 \\
\hline 2 & 6.413 & $\begin{array}{c}\text { ethylben } \\
\text { zene }\end{array}$ & $\begin{array}{c}\mathrm{C} 8 \mathrm{H} 1 \\
0\end{array}$ & 5.015 & 92 \\
\hline 3 & 6.692 & $\begin{array}{c}\text { P- } \\
\text { xylene }\end{array}$ & $\begin{array}{c}\mathrm{C} 8 \mathrm{H} 1 \\
0\end{array}$ & $\begin{array}{c}14.01 \\
4\end{array}$ & 98 \\
\hline 4 & 7.376 & $\begin{array}{c}\text { O- } \\
\text { diphenyl }\end{array}$ & $\begin{array}{c}\mathrm{C} 8 \mathrm{H} 1 \\
0\end{array}$ & 6.875 & 98 \\
\hline 5 & 7.697 & $\begin{array}{c}\text { n- } \\
\text { Nonane }\end{array}$ & $\begin{array}{c}\mathrm{C} 9 \mathrm{H} 2 \\
0\end{array}$ & 0.985 & 97 \\
\hline 6 & 9.350 & Cumene & $\begin{array}{c}\mathrm{C} 9 \mathrm{H} 1 \\
2\end{array}$ & 1.514 & 92 \\
\hline 7 & 9.601 & $\begin{array}{c}\text { 3- } \\
\text { ethyltol } \\
\text { uene }\end{array}$ & $\begin{array}{c}\mathrm{C} 9 \mathrm{H} 1 \\
2\end{array}$ & 7.068 & 96 \\
\hline 8 & 9.698 & $\begin{array}{l}\text { O-ethyl } \\
\text { toluene }\end{array}$ & $\begin{array}{c}\mathrm{C} 9 \mathrm{H} 1 \\
2\end{array}$ & 3.224 & 96 \\
\hline 9 & 9.874 & $\begin{array}{c}\text { Mesityle } \\
\text { ne }\end{array}$ & $\begin{array}{c}\mathrm{C} 9 \mathrm{H} 1 \\
2\end{array}$ & 3.254 & 97 \\
\hline 10 & $\begin{array}{c}10.13 \\
6\end{array}$ & $\begin{array}{l}\text { Trimeth } \\
\text { ylene }\end{array}$ & $\begin{array}{c}\mathrm{C} 9 \mathrm{H} 1 \\
2\end{array}$ & 3.401 & 97 \\
\hline
\end{tabular}

\section{Conclusion}

Sulfate radical can effectively degrade organic pollutants in secondary biochemical effluent of papermaking wastewater under acidic to neutral conditions. The increase of $\mathrm{pH}$ range of advanced oxidation method based on sulfate radical is of great significance in the practical engineering application of advanced oxidation technology. $\mathrm{PH}$ value has an important effect on CODcr degradation rate and chromaticity removal rate of secondary biochemical effluent of advanced treatment of papermaking wastewater by sulfate radical The effects are as follows: $\mathrm{pH} 3.0 \geqslant \mathrm{pH} 7.0>\mathrm{pH} 10.0$.

The changes of substances before and after the oxidative degradation of sulfate radical show that sulfate radical can effectively degrade the refractory organic pollutants in the secondary biochemical effluent of papermaking wastewater. The decrease of the relative content of benzene substances and the obvious increase of alkanes indicate that the pollutants have been effectively oxidized and degraded.

\section{References}

1. P. Qiao, J. Wu, H. Li, et al. Plasmon Ag Promoted Solar-Thermal Conversion on Floating Carbon Cloth for Seawater Desalination and Sewage Disposal.Acs Applied Materials \& Interfaces, 2019.

2. K. Koop, P. Hutchings.Disposal of sewage to the ocean - Still a sustainable solution?. Marine Pollution Bulletin, 2019, 145. 
3. A. Ding, R. Zhang, H. H. Ngo, et al. Life cycle assessment of sewage sludge treatment and disposal based on nutrient and energy recovery: A review. Science of The Total Environment, 2021, 769:144451.

4. B. S. Choudri, Y. Charabi. Health effects associated with wastewater treatment, reuse, and disposal. Water Environment Research, 2019, 91(10).G.R. Mettam, How to prepare an electronic version of your article, in: B.S. Jones, R.Z. Smith (Eds.), Introduction to the Electronic Age, E-Publishing Inc., New York, 1999, pp. 281-304.

5. Chen N, Tao S, Xiao K, et al. A one-step acidification strategy for sewage sludge dewatering with oxalic acid. Chemosphere, 2020, 238(Jan.):124598.1-124598.11.P.G. Clem, M. Rodriguez, J.A. Voigt and C.S. Ashley, U.S. Patent 6,231,666. (2001). 